\title{
The Evaluation of Excellent Service Readiness in Tourism Villages of Pagaralam Area
}

\author{
Hariman Hariman ${ }^{1,{ }^{*}}$ Dilla Sayangbatti ${ }^{2}$, Taslim Taslim ${ }^{3}$ \\ 1,2,3 Politeknik Pariwisata Palembang \\ *Corresponding author. Email: hariman@poltekpar-palembang.ac.id
}

\begin{abstract}
Nowadays, the development is done gradually, one of the current developments is the development of tourist villages in Pagar Alam city which is spread in 6 (six) locations, it was presented during the socialization of tourism villages and sustainable development in Villa Gunung Gare Pagar Alam by the Head of Pagar Alam City Tourism Office recently.The type of research approach used by the researchers is a descriptive method with reference to a qualitative approach. The non -probability sampling technique used in sampling taken in this study uses a purposive sampling technique. The researcher conducted direct interviews with the manager as well as the officials who is in charge of tourist destinations in Pagar Alam city.The data analysis technique used is a qualitative descriptive analysis which is aimed to obtain information or conclusions about the evaluation of the excellent service readiness conducted by the manager of the Tourist Village which is the target or priority of Pagar Alam.The Excellent Service Readiness in Pagar Alam Area of Tourist Villages on the average result value is 2.37 can be concluded that the readiness of the excellent service for 6 (six) tourist villages is quite ready. The Excellent service indicators of Dewi Sekopi and Gunung Dempo tourist villages are ready to provide the excellent service measured by ability, attitude, appearance, attention, action, and accountability.
\end{abstract}

Keywords: Readiness, Excellent Service, Tourist Village, Pagaralam Area

\section{INTRODUCTION}

The Pagaralam city government through the Tourism Office in collaboration with the village community collecting the data and designing tourism villages destinations which are natural and having a village atmosphere and and also it has a tourism selling value. A tourism village that has opportunities for village tourism activities is required to support the local community's economy and the sale of local product which runs successfully. The management of tourism villages and security for tourists must be ready to be carried out by the local community. Tourism villages that has been the parts of the Tourism Office program in Pagaralam area consist of Gunung Agung Lama tourism village, Dewi Sekopi, Tebat Benawa, Pelang Kenidai, and Rimba Candi.

Tourism Vollage and Besemah Coffee School as the place to improve the quality of coffee in Pagaralam city and provide the economic added value for the local coffee farmers. Pagaralam as one of the largest coffee producers in Indonesia keeps increasing the efforts to improve the quality of coffee from hulu (upstream) to hilir (downstream) with many parties and it is part of collaboration with the community as well as a new business model in the sector of agrotourism.

The synergy of pentahelix in the development of tourism village that consists of government, academics, business people, media and communities have full responsibility in synergizing to assist the government in determining the direction of policy for developing the tourism villages in Pagaralam. One of the pentahelic elements, namely Palembang Polytechnic of Tourism collaborating with Pagaralam government to a tourism village assistance program in planning, management, monitoring, and evaluation in the context of developing the excellent service in a tourism village in Pagaralam area. 
According to the data taken from the current social counseling held by the Center for Research and Community Service (P3M) on March 30 ${ }^{\text {th }}, 2021$ in Pagaralam, the city government of Pagaralam prepared a sustainable tourism sector development planning until 2025. The development is currently being done step by step, one of them is the development of the tourism village which is in Pagaralam that has been spread over six locations. It was conveyed by the head of the Tourism Office of Pagaralam city as a speaker in the socialization of tourism villages and sustainable development activity at Villa Gunung Gare Pagaralam. Pagaralam tourism village managers from the local community do not understand the standard of excellent service that must be done starting from the arrival (pre-arrival) during the tourists visit (operation service) and after departures (post-visit), so that competence-based human resource training and competency certification are strongly required. The center for Research and Community Service (P3M) is followed more in depth evaluation, relying on behavioral observations, it is expected that more complex and valid the data can be obtained in term of the improvement of participant behavior in providing tourism services. The community service has been done regarding the excellent service to theTourism Managers and The Tourism actors in the tourism villages of Pagaralam area in order to provide the training based on skill improvement through skills training.

The understanding of tourism actors in providing the excellent service that follows health, hygiene and security procedures for guests and visitors as well as to improve the welfare and productivity of the community as well as expanding for for tourism actors, especially tourism villages based home stay, the level of excellent service for tourists used home stay tourism services in the tourism villages could run optimally so that the tourists can interact directly with the local community.

\subsection{The Excellent Service}

Excellent Service is one of the important components that must be carried out by all companies in order to survive in the midst of global competition nowadays. Excellent service is an action that gives customers what they expect when they need it, by the way that they want (Saleh, 2010)[7]. The use of Atep theory in this study where the researchers evaluate for the excellent service readiness taken from six variables that can be used as the standards so that they can be used in the tourism villages of Pagaralam area in providing tourist satisfaction for both managers, or tourism actors and the local community. Atep (2003)[2] developed 'the culture of excellent service into Six A, which including Ability, Attitude, Appearance, Attention, Action and Accountability'. The research variables and indicators can be seen based on the following tables:

Table 1. Variables and indicators of excellent service

\begin{tabular}{|c|c|}
\hline No & Tourism Villages of Pagaralam area \\
\hline 1. & Ability \\
\hline a. & $\begin{array}{l}\text { Tourism village managers maintain good relation } \\
\text { with travellers }\end{array}$ \\
\hline b. & $\begin{array}{l}\text { Tourism village managers understand the } \\
\text { products that they sell }\end{array}$ \\
\hline 2. & Attitude \\
\hline a. & $\begin{array}{l}\text { Tourism village managers are friendly with } \\
\text { tourists or travellers }\end{array}$ \\
\hline b. & $\begin{array}{l}\text { Tourism village managers are polite to tourists or } \\
\text { travellers }\end{array}$ \\
\hline 3. & Appearance \\
\hline a. & $\begin{array}{l}\text { Tidy and Cleanliness of the tourism actors during } \\
\text { serving guests }\end{array}$ \\
\hline b. & $\begin{array}{l}\text { Tidy and Cleanliness of the tourism managers } \\
\text { when serve guests }\end{array}$ \\
\hline 4. & Attention \\
\hline a. & $\begin{array}{l}\text { the tourism village managers understand the } \\
\text { tourism needs }\end{array}$ \\
\hline b. & $\begin{array}{l}\text { the tourism village managers provide security and } \\
\text { comfort to tourists or travellers }\end{array}$ \\
\hline c. & $\begin{array}{l}\text { the tourism village managers serve without } \\
\text { seeing the social status of any travellers or } \\
\text { visitors }\end{array}$ \\
\hline 5. & Action \\
\hline a. & $\begin{array}{l}\text { Timeliness in serving done by tourism village } \\
\text { managers }\end{array}$ \\
\hline b. & $\begin{array}{l}\text { the tourism village managers say thanks after } \\
\text { giving service }\end{array}$ \\
\hline 6. & Accountability \\
\hline a. & $\begin{array}{l}\text { the tourism village managers accept guest } \\
\text { complaint }\end{array}$ \\
\hline b. & $\begin{array}{l}\text { the tourism village managers help to find any } \\
\text { problem solving }\end{array}$ \\
\hline
\end{tabular}

Ability is a certain knowledge and skills that are absolutely necessary to support excellent service programs which includes abilities in the field of work that are occupied to carry out effective communication, develop motivation and use public 
relations as an instrument in bringing the relationship into and out of the organization or company.

Attitude is a behavior or temperament that must be highlighted when it deals with customers that can be adapted to the conditions and wishes of the customer. Appearance is a person's ability, both physical and non physical, which is able to reflect the confidence and credibility of the other party.

Attention is full concern for customers needs and desiresas well as understanding of suggestions and criticisms from customers.

Action is an at in any real activities that must be carried out in providing services to customers.

Accountability is a responsibility that is an attitude of partiality to customers as a form of concern to avoid or to minimize customers' lost or dissatisfaction.

\subsection{Tourism Villages in Pagaralam}

Inskeep, (1991:166)[3] defines "Village tourism, where the small groups of tourist stay in or near traditional, often remote village and learn about village life and the local environtment".

Simanungkalit et al, (2017:20)[8] explains that there are several levels of development of tourism villages which are divided into three levels, namely the Embryo Tourism Village is a village that has tourism potential which can be developed into a tourism village and there has been a community or village movement to promote tourism, manage it into a tourism village.

Developing tourism village is an embryo of tourism village that has been managed by the community and village government, there has been a community or village self assistance for it's management, has been starting to carry out promotions and it have made tourists been interested in visiting tourism villages. Maju tourism village is a tourism village that has been developing with tourists visit continually and it is managed professionally with 14 formation of management forums, such as cooperatives (koperasi) or Village Enterprise (badan usaha milik desa) whereas they have been able to carry out promotions and marketing well.

The development of tourism villages which previously more orientedly to greedy tourism that has the meaning of greediness which is only concerned to the large number of tourists come without paying attention to the sustainability aspect and must be changed immediately into the concept of green tourism which is more friendly to the environment and local culture. This condition eventually leads to create the concept of developments of tourism villages that hold the principles, one of them (Simanungkali et al, 2017:14)[8].

The tourism village of Pagaralam area is a developing tourism village where tourism villages such as Gunung Agung Lama (Dewi Sekopi), Tebat Benawa, Pelang Kenidai, Rimba Candi, Tebat Lereh, and Gunung Dempo have been confirmed and have been declared through the decree that is issued by the head of tourism office of Pagaralam.

Pagaralam tourism with the membership structure of tourism village made by considering the role of community as an important subject or actor in tourism development can they can work together and become a partner with relevant stakeholders in improving the quality of tourism development in the region to build and to foster positive attitudes and also supports from the community as hosts through the realization of Sapta Pesona values for the growth and development of tourism in the region. Furthermore, it's advantages for the regional government and community welfare, it is important to form a tourism village. The tourism village of Pagaralam area has tourism potential in working are of each region, suppoting tourism facilities, and village interaction to tourism visit.

The Pelang Kenidai tourism village has the second runner achievement of Anugrah Pesona Indonesia awards in the national most popular traditional village competency event in 2020. Dewi Sekopi tourism village also won the fourth champion of world champion award in the category of " the strong bitter' category at the world coffee competition in France in 2020.

\section{METHODOLOGY}

The type of research method approach used by the researchers is a descriptive method with reference to a qualitative approach. The qualitative approach was chosen due to the research intention to understand the phenomenon of what is experienced $b$ the researcher subject holistically, and by the way of description in the form of words and languages, in a special natural context and by utilizing various scientific methods (Lexy Moleong, 2005:6)[4].

\subsection{Informant Selecting Technique}

According to Sugiyono (2010:119)[9] sampling technique is "sampling technique to determine the sample used in research." The sampling technique used by the researchers is non-probability sampling. 
The non-probability sampling technique used in this study is a purposive sampling technique.

\subsection{The Types and Data Sources}

Qualitative data is the data in the form of information,statements, facts about the objects that are useful, clear and actually support this research not in the form of numbers and it can not be measured directly in numbers. In this study, the researchers also use primary data and the secondary data.

According to Arikunto (2002:107)[1] what is meant by the data source in the study is the subject in which the data can be obtained. If the researchers use questionnaires or interviews in collecting the data, the the source of the data is called respondent, namely the person who responds or answer the researcher's questions, both written and oral questions. Furthermore, Arikunto says, if the researcher uses observation techniques, the source of the data can be in the form of objects, motions or process os something. If the researchers use the documentation, then the document or rcord is the source of the data. Based on the statement above, the researchers obtained various resources, both directly and indirectly, which can be used as sources of the data in this study, so that the researchers obtained the data both primary and secondary data.

\subsection{The Technique of data collection}

In this study, the researchers use two kinds of data based on the clarification, variety and the resources such as The technique of Document study done by collecting, reading and recording or concerned information, either the data that is available in the books of excellent service and the tourism village assistance program or from the results of previous researches, the journal of excellent service development in accordance with the problems faced in this study.

The technique of the interview done step by step that is the interview done based on the schedule of the researchers after being allowed by the resources. The interview, according to Nazir (1998:234)[6] is the process to obtain the information used for a research by giving an interview face to face between interviewer and interviewee or a respondent using a tool namely interview guidance.

\subsection{Data Validity}

In conducting a research, it is necessary to have a measuring instrument as an indicator to analyze the research subject. This measuring instrument will be an initial data set which will then become a reference material to be analyzed and conclusions can be drawn. In this study, researchers used data validation with triangulation techniques. According to Moleong (2001)[5] triangulation is a technique of checking the validity of data by utilizing something other than the data for checking purposes or as a comparison, namely triangulation of sources, methods and theories. Sugiyono (2012)[10] states that triangulation is checking data that has been obtained from several different sources, so that from different sources it can answer phenomena that occur in the field.

\subsection{Analysis of Qualitative Descriptive Method}

To obtain information or conclusions regarding to the evaluation of the excellent service readiness that is carried out by the manager of the Tourism Village that is the target or priority of Pagaralam, the researchers distributed questionnaires directly both to the managers and to the official in charge of tourist destinations in the city of Pagaralam by measuring quantitatively to the variables given, then transfer the quantitative value into a qualitative predicate. Furthermore, the researchers distributed questionnaires that contain with six questions variables that included: Ability, Attitude, Appearance, Attention, Action and Accountability.

\section{RESULT AND DISCUSSION}

Readiness of Excellent Service in Dewi Sekopi Pagaralam Tourism Village, respondents who gave value responses to Dewi Sekopi tourist village are three people, they are Mr. Anjas Hariansyah (Head of Industry and Destinations of Pagar Alam Tourism Office), Mrs. Widya Wati (Head of Economy creative Pagar Alam Tourism Office), and Mr. Gules (manager of Dewi Sekopi). Managers and respondents who serve as Head of the Department of Tourism stated that they are ready for excellent service for Dewi Sekopi tourism village.

Readiness of Excellent Service in the Tourism Village of Tebat Benawa Pagaralam respondents who gave value responses to Dewi Sekopi tourist village are three people, They are Mr. E.Martadinata (Head of Human Resources and Destinations of Pagar Alam 
Tourism Office), Mr. Anjas Hariansyah (Head of Industry and Destinations Tourism Office of Pagar Alam), and Mr. Marpel (manager of Tebat Benawa). Managers and respondents who serve as Head of the Department of Tourism states that they are almost very ready or in other words are close to being very ready for excellent service for the tourism village of Tebat Benawa.

Respondents who gave value responses to Pelang Kenidai tourism village are two people, They are Mr. Anjas Hariansyah (Head of Industry and Destinations at the Pagar Alam Tourism Office), and Ms. Delta Nurcahyani (one of Pelang Kenidai's administrators). as the Head of the Department of Tourism, states that they are almost very ready or in other words they are close to being very ready for excellent service for Pelang Kenidai tourism village.

Readiness of Excellent Service in Pagaralam of Rimba Candi Tourism Village Respondents who gave value responses to Rimba Candi tourism village are two people, they are Mr. Anjas Hariansyah (Head of Industry and Destinations at the Pagar Alam Tourism Office), and Mr. Taryono (one of Rimba Candi administrators or managers and respondents who serve as Head of the Department of Tourism states that they are almost ready or in other words are close to being ready for excellent service for the Rimba Candi tourist village.

Readiness of Excellent Service in the Tourism Village of Tebat Lereh Pagaralam Respondents who gave value responses to the tourism village of Tebat Lereh are two people, they are Mr. Anjas Hariansyah (Head of Industry and Destinations at the Pagar Alam Tourism Office), and Mr. Yuanda (one of the administrators or managers and respondents who serve as Head of the Department of Tourism states that they are ready or in other words quite ready for excellent service for Tebat Lereh tourism village.

Mr Edi Supardi ( the manager of Gunung Dempo tourism village) Managers and respondents who serve as Head of the Department of Tourism states that they are ready or in other words almost ready for excellent service for the Gunung Dempo tourism village

From the results of the potential analysis of the tourism village, it has potential components that support, namely: The existence of attractions or attractions that are unique to the village itself. The existence of tourism facilities and accommodation such as lodging facilities eating and drinking facilities, hawker or souvenir centers, visitor centers. There are tourist activities such as weaving, enjoying the scenery and others. There is general development as an effort to create a tourist destination that provide the best services for tourists, including: division of zones or areas, visitor management, and communication services. Tourism villages must have excellent service readiness, this is important to increase market share, increase profits, and improve the reputation of tourism villages so as to increase tourist visits in terms of improving the community's economy. To see the readiness of prime service for tourism villages in Pagaralam, the researchers analyzed the results of interviews as follows:

Variable ability (ability), the Tourism Village Manager fosters good relations with tourists by having knowledge and skills in meeting tourist needs which are absolutely necessary to support excellent service programs. This capability is still being improved so that good relations with tourists can run harmoniously so that the readiness of this ability must be in line with the potential of tourism villages in Pagaralam. Pagaralam Tourism Office has collaborated with academics in a synergistic manner in providing an understanding of the readiness of capabilities with the existence of Technical Guidance so that they have ready capabilities by having knowledge and skills in carrying out tourism village operations. The Tourism Village Manager understands the products sold by having the ability in the field of work that is occupied in carrying out effective communication, this is done by promoting a satisfying and safe experience for tourists and the community.

Attitude variable, tourism villages have behaviors that must be highlighted when dealing with tourists that can be adapted to the conditions and wishes of these tourists by being friendly and polite. This is a tourism village that requires an increase in hospitality. The implementation of Sapta Pesona needs to be improved by the tourism village manager and the local community so that the community must be ready for the upcoming changes in their village. Tourists who visit with various cultures and customs that they bring. The arrival of foreign and domestic tourists must also be prepared to be faced with filtration so as not to damage attitudes and values, including the values of local wisdom that exist in the village. Thus, the attitudes and values that are 
maintained will also be able to maintain the authenticity of the village.

The appearance variable (appearance) can be seen from the tidiness and cleanliness of the Tourism Village Managers and Actors when serving where these abilities are both physical and non-physical which can reflect the confidence and credibility of the tourists. There is no standard of appearance made by the tourism village manager, and every manager and actor must implement it when meeting with tourists. Physical appearance includes wearing a standard uniform, formal work shoes with standard colors (black, brown, or according to the color of the clothes), hair must be neat, for the front liner/marketing part, men must be short, women are not shoulder-length or in a bun, with visible earlobes, women wear.Make Up so that the face looks fresh using identification in a visible place and pay attention to the cleanliness of the body, nails, hair and face and Clean and ironed clothes and use a standard belt for men. Non-physical appearance includes how to stand, walk, sit, shake hands, eye contact, look at the other person and smile by showing interest or interest in the subject matter and facial expressions, must be cheerful-looking, show a smiling expression not only on the lips, but also on the face especially in the eyes.

Attention variable, where the Tourism Village Manager is still not ready to understand the needs and provide a sense of security and comfort must be increased full concern for customers, both related to attention to customer needs and desires as well as understanding of suggestions and criticism from tourists, attention to tourists by greeting politely and friendly, showing a friendly smile, paying attention to the needs and desires of tourists with polite language, listening and understanding everything that is conveyed by tourists with understanding and empathy, inviting tourists to wait in a place provided politely, quickly serving their needs and the wishes of these tourists, remain in a friendly attitude, prioritizing what the tourists need or want.

Variable action (action), actions in various real activities that must be carried out in providing services to tourists with punctuality in serving by the Tourism Village Manager and saying thank you at the end of the service.Attention (attention) the emphasis is on how we give our attention to the needs or desires tourists and continued with action (action) on what the needs of the tourist where if you are not sure and it is better to confirm politely.

The variable of responsibility (accountability), has an attitude of siding with the customer as a form of concern to avoid or minimize losses or customer dissatisfaction. The Tourism Village Manager accepts guest complaints and helps provide solutions. The excellent service variable is an attitude of responsibility if it is carried out correctly and wholeheartedly, it can minimize the occurrence of customer dissatisfaction, guests or tourism village partners.

This study is aimed at determining to the readiness of excellent service in Pagaralam tourism village in order to support the development of tourism by being a policy to increase the readiness starting from the level of readiness (not ready, preliminary, ready, receptive and optimal) by focusing to pay attention to the variables of excellent service and research indicators.

Table 2. The excellent service readiness in the tourism village of pagaralam area

\begin{tabular}{|l|l|l|}
\hline No & Tourism Village & Value \\
\hline 01 & Gunung Dempo & 2.53 \\
\hline 02 & Tebat Lereh & 2.08 \\
\hline 03 & Rimba Candi & 2.3 \\
\hline 04 & Pelang Kenidai & 2.1 \\
\hline 05 & Tebat Benawa & 2.6 \\
\hline 06 & Dewi Sekopi & 2.66 \\
\hline No & Tourism Village & \multicolumn{2}{|c|}{ Value } \\
\hline & & $14.27 / 6$ \\
\hline & Average & 2.37 \\
\hline
\end{tabular}

Based on the table data above related to The Excellent Service Readiness in The Tourism Village of Pagaralam Area. On average results with a value of 2.37 it can be concluded that the excellent service readiness for 6 (six) tourism village is quite ready. Based on the results of interviews with the Pagaralam Tourism Office and the Tourism Village Manager in Pagaralam where the tourism village has its own characteristics, this is seen from the potential in the village so that it deserves to be used as a tourism village. The management of a tourism village as a tourist attraction is not only limited to its designation as a tourism village. The tourism village community in Pagaralam has a desire to improve the economy of the community and develop the potential that exists 
in the tourism village, the active role of the community based on the decree of the Head of the Pagaralam Tourism Office can be seen from the composition of tourism village membership.

\section{CONCLUSIONS AND SUGGESTION}

Based on the evaluation of The Excellent Service Readiness in The Tourism Village of Pagaralam Area can be seen from all the excellent service indicators, Dewi Sekopi and Gunung Dempo Tourism Villages are ready to provide excellent service and Tebat Benawa and the tourism villages of Tebat Benawa, Pelang Kenidai, Rimba Candi and Tebat Lereh are quite ready to provide the excellent service measured by the ability, attitude, appearance, attention, action, and accountability. Increased consolidation is needed between the Tourism Village Manager and the Government and academics so that all tourism villages in Pagaralam have readiness to provide the excellent service by meeting all these indicators.

Standards must be made of the ability, attitude, appearance, attention, action, and accountability using the variables of each indicator by the Tourism Village Manager and each manager and actor must carry it out when meeting with the tourist. It is necessary to prepare this standard of appearance, which is very useful so that the tidiness and cleanliness of Tourism Village Managers and Actors when serving, having the ability to provide both physical and non-physical services. Attention, where it is necessary to prepare a media survey for tourists to improve Tourism Village Managers in understanding needs and providing a sense of security and comfort, full concern for customers must be increased, both related to attention to customer needs and desires as well as understanding of suggestions and criticisms from customers. traveler. Tourism Village Managers must prepare standards for dealing with tourist complaints and helping to provide solutions to achieve customer satisfaction with full responsibility (accountability).

\section{AUTHOR'S CONTRIBUTION}

Hariman: Performed research, lead author, coanalyzed data. Dilla Sayangbatti: corresponding author, analyzed data, performed research. Taslim: co-authors, supervised site survey.

\section{ACKNOWLEDGMENTS}

Special thanks to Pagaralam Tourism Office and Pagaralam Tourism Village Managers

\section{REFERENCES}

[1] Arikunto, Suharsimi. 2002. Metodologi Penelitian. Penerbit PT. Rineka Cipta. Jakarta

[2] Atep, Adya Barata. 2003. Dasar-Dasar Layanan Prima. Jakarta: PT Elex Media Komputindo

[3] Inskeep, Eduard. 1991. Tourism Planning: An Integrated and Sustainable

[4] Moleong Lexy J., 2005. Metodologi Penelitian Kualitatif, PT Remaja Rosda Karya: Bandung

[5] Moleong Lexy J., 2001. Metodologi Penelitian Kualitatif, PT Remaja Rosda Karya: Bandung

[6] Nazir. 1998. Metode Penelitian. Jakarta: Ghalia Indonesia

[7] Saleh, A Muwafik. 2010.“ Manajemen Pelayanan “. Pustaka Pelajar, Jakarta

[8] Simanungkalit, dkk. (2017). Buku Panduan Pengembangan Desa Wisata Hijau. Jakarta: Kementerian Koperasi dan Usaha Kecil Menengah

[9] Sugiyono. 2010. Metode Penelitian Pendidikan Pendekatan Kuantitatif, kualitatif, dan R\&D. Bandung: Alfabeta

[10] Sugiyono. 2012. Metode Penelitian Kuantitatif Kualitatif dan R\&B. Bandung: Alfabeta 